\title{
VONTADE DE PODER VERSUS NORMATIVIDADE: O QUE O NAZISMO NOS ENSINA?
}

WILL OF POWER VERSUS NORMATIVITY: WHAT DOES NAZISM TEACHERS US?

VOLUNTAD DE PODER VERSUS NORMATIVIDAD: ¿QUÉ NOS ENSEÑA EL NAZISMO?

Rosivaldo Toscano dos Santos Júnior ${ }^{1}$

Lenio Luiz Streck ${ }^{2}$

Resumo: O ativismo judicial ganhou ampla simpatia de setores populares e também entre os atores jurídicos. Tal se explica pela histórica baixa confiança nas instituições estatais e pelo reposicionamento do Judiciário no Pós-Guerra, dentro da ideia de Estado Democrático de Direito, em que a função jurisdicional assume a tarefa de concretizar uma Constituição transformadora. Ocorre que o desapego à normatividade e à aposta na vontade do juiz, dentro de uma conjuntura historicamente marcada pelo autoritarismo, gera riscos. O exemplo do Judiciário nazista serve de alerta às consequências de se apostar na vontade dentro de uma conjuntura de poder. Da autoridade ao autoritário é só um

1 Doutorando em Ciências Jurídicas pela UFPB. Mestre em direito pela UNISINOS. Professor da Escola da Magistratura do Rio Grande do Norte - ESMARN e Juiz de Direito em Natal, RN, Brasil (rosivaldotoscano@hotmail.com).

2 Pós-doutor em direito. Professor dos cursos de Mestrado e Doutorado da UNISINOS, São Leopoldo, RS, Brasil. Ex-Procurador de Justiça, Advogado (lenios@globo.com). 
pequeno passo para o juiz, mas um grande abismo para a constitucionalidade. A salvaguarda contra os riscos do ativismo judicial reside no atrelamento à normatividade; aos textos que, na atribuição de sentidos autêntica, dentro de uma tradição, revela a norma do caso concreto.

Palavras-chave: Ativismo judicial. Vontade de poder. Judiciário nazista. Normatividade.

Abstract: Judicial activism has gained widespread sympathy from popular sectors and also among the legal actors. This is explained by the historical low confidence in government institutions and the repositioning of the Judiciary in the Post-War period, within the idea of a democratic state in which the judicial function assumes the task of consolidating a transformative Constitution. However, underestimating the normativity and the will of the judge, within a historical context marked by authoritarianism, generates risks. The example of the Nazi judiciary serves as a warning in regard to the consequences of relying on the will within a context of power. Moving from authority to authoritarian is only a small step for the judge, but a great chasm for constitutionality. One safeguard against the risks of judicial activism is to stick to normativity; and to the texts that, in the attribution of authentic meanings, within a tradition, reveal the norm of the concrete case.

Keywords: Judicial activism. Will to power. Nazi judiciary. Normativity.

Resumen: El activismo judicial ganó una amplia simpatía de sectores populares y también entre los actores jurídicos. Ello se explica por la histórica baja confianza en las instituciones estatales y por el reposicionamiento del Poder Judicial en el período de posguerra, dentro de la idea de Estado Democrático de Derecho, en el que la función jurisdiccional asume la tarea de concretizar una Constitución transformadora. Lo que ocurre es que el desapego a la normatividad y la apuesta en la voluntad del juez genera riesgos, dentro de una coyuntura históricamente marcada por el autoritarismo. El ejemplo del Poder Judicial nazi sirve de alerta 
para las consecuencias de apostar en la voluntad dentro de una coyuntura de poder. De la autoridad a lo autoritario hay solo un pequeño paso para el juez, pero un gran abismo para la constitucionalidad. La salvaguarda contra los riesgos del activismo judicial reside en la sujeción a la normatividad; a los textos que, en una auténtica atribución de sentidos, dentro de una tradición, revela la norma del caso concreto.

Palabras clave: Activismo judicial. Voluntad de poder. Poder Judicial nazi. Normatividad.

INTRODUÇÃO

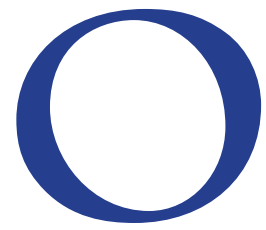

presente escrito inicialmente analisa a emergência do protagonismo judicial no Brasil, fenômeno inserido no contexto pós-Constituição de 1988, mas em um ambiente ainda marcado pela dominação do estamento, que controla as posições chaves no Estado. Diante de um texto normativo atributivo de uma vasta gama de direitos e da insuficiência/desinteresse dos detentores do aparato estatal de efetiválos, o Judiciário ocupou o lugar de destaque e de salvador da pátria. Mas em meio a um contexto secular de baixa efetividade das regras em detrimento dos interesses estamentais, a normatividade - como critério de justiça e de delimitação da função jurisdicional - não vingou. O protagonismo deu lugar ao ativismo judicial moldado pela vontade de poder do julgador.

A partir dos estudos de Ingo Miller sobre o papel da Justiça alemã e a sua contribuição ao nazismo, mostra-se como o baixo apego à normatividade abre as portas para o exercício da vontade de poder e, com ele, o totalitarismo e a violação de direitos fundamentais. Traçando um paralelo com o nascimento e a consolidação de um regime totalitário, o estudo faz uma crítica ao ativismo judicial - que tem a decisão como um ato de vontade. Mas qual seria essa vontade? A partir dos estudos de Enrique Dussel, face à reconstrução da ideia de poder como dominação tão em voga nas Américas, palco do grande genocídio, o autor alerta para a deslegitimação do Poder quando se relega e se desconsidera o poder 
potencia em benefício do mero poder potestas. O poder, assim, deslegitima-se. A partir de então, o estudo aprofunda o exemplo do Judiciário na Alemanha nazista para assinalar que a decisão judicial não pode ser um ato de vontade de poder, mas uma decisão que necessariamente se vincula e deve ser submetida à normatividade e à tradição.

É a normatividade que deve delimitar a esfera de poder aos que exercem jurisdição. Como o próprio texto alerta, o juiz não recebeu um cheque em branco para fazer o que quiser ou agir de acordo com seus valores pessoais. E o julgador não pode fazer uma atribuição de sentido que não seja autêntica, isto é, fora da história e da tradição porque o sentido na linguagem já está dado intersubjetivamente, não estando à escolha de quem possui uma parcela de jurisdição.

PANORAMA

O Brasil, assim como os demais países que se originaram de colônias de exploração, sempre foi marcado pela baixa confiança nas instituições públicas por parte da população e pela também baixa consciência democrática - o que facilita a instauração de regimes de exceção.

A baixa confiança nas instituições estatais tem origem funcional e estrutural. Historicamente sequestradas pelo estamento 3 que as mantinha em seu domínio como instrumento de mando e desmando, as instituições públicas aqui sempre serviram para a obtenção/usurpação de renda e para a manutenção do poder por meio da ocupação de postos estratégicos, ora como cabide de empregos, ora como viabilizadora do desvio de sua finalidade originária de justiça distributiva.

E assim, os recursos públicos que, fundamentalmente, deveriam ser utilizados em prol da coletividade, aqui foram destinados, prioritariamente, à mantença dos privilegiados detentores dos meios institucionais.

Esse ambiente de histórica expropriação, exploração e usurpação do público pelo privado se fez de maneira compartilhada - externamente pela matriz do

3 FAORO, Raymundo. Os donos do poder: formação do patronato político brasileiro. 4. ed. São Paulo: Globo, 2008, p. 913. 
momento 4 e internamente pelo estamento secular. A democracia é burlada, nesse contexto, por meio da captação ilícita de votos. À vista (por meio de escambo ou compra) ou a prazo (pela venda de futuras vantagens profissionais, pessoais ou comerciais), o mau exemplo do estamento contamina e, assim, todas as camadas sociais participam (ou tentam participar) da dilapidação (na proporção de seu poder dentro da sociedade) do patrimônio coletivo, em um processo de desnaturação, corrupção e desvirtuamento do sistema representativo.

E com isso, ainda na esfera da representação política, as vedações do art. $14, \S 7^{\circ}$ da Constituição da República (inelegibilidades) não são suficientes para impedir a formação de dinastias eleitorais e a profissionalização da atividade político-partidária. Determinados patronímicos passam de geração para geração nos cargos eletivos. É a degradação da representação popular por meio do carreirismo político-familiar que se apropria da eletividade como se esta constituísse um bem transmissível hereditariamente. É o caudilhismo. Aliado a isso, os escandalosos investimentos empresariais em campanhas ${ }^{5}$ por parte de grandes grupos econômicos geram corrupção e desigual e elitizada composição de nossos cargos eletivos. ${ }^{6}$

Assim, as instituições democráticas e os poderes Executivo e Legislativo possuem baixa credibilidade e seus agentes são (re)conhecidos como membros desse estamento que atua vampirizando a esfera pública.

4 Leia-se, inicialmente, Portugal, até início do Século XIX; depois compartilhando a exploração com a Inglaterra. Já no Século XX, principalmente pelos Estados Unidos, que enxergam não só o Brasil como toda a América Latina como área de exploração econômica (SCHILLING, Voltaire. Estados Unidos e América Latina: da doutrina Monroe à Alca. 5. ed. Porto Alegre: Leitura XXI, 2002).

5 Não é factível que corporações - que são entes voltados para a geração de lucros aos seus dirigentes e acionistas -, de repente, em um ato de ingênua bondade, resolvam doar a fundo perdido milhões e milhões de reais a candidatos. A conta não fecha. A porta não bate. Mas, mesmo assim, o sistema se perpetua. Quando a boca cala, o silêncio fala. Assim, recusa-se a chamar isso de doação. Nesse entendimento, empresa não doa. Investe. Ou alguém já viu alguma multinacional distribuindo seus lucros nas ruas? A conclusão que se tira é que esse modelo gera corrupção. E a sociedade é quem paga os prejuízos. Não é factível que seja diferente. E nem é aceitável que se fique inerte. Somente um baixo grau de desenvolvimento democrático permite esse eloquente silêncio.

6 REIS, Thiago. Quase metade da nova Câmara dos Deputados será formada por milionários. G1 Eleições, do Portal Globo.com. Disponível em: http://g1.globo.com/politica/ eleicoes/2014/blog/eleicao-em-numeros/post/quase-metade-da-nova-camara-dos-deputados-sera-formada-por-milionarios.html. Acesso em: 23 jul. 2015. 
O Judiciário, também historicamente controlado pelo estamento, não era um Poder que fizesse frente aos outros dois - isto quando não servia à razão instrumental de dar uma carapaça de legalidade ao status quo na manutenção das relações desiguais de poder na sociedade.

Mas com a constitucionalização dos Direitos Fundamentais, fenômeno que no Brasil efetivamente só ocorreu com o advento da Carta de 1988 - uma vez que reconheceu tais direitos como de aplicação imediata ${ }^{7}-$, abriu-se um fosso entre a normatividade e a realidade social. Os Direitos Fundamentais, que nos países centrais foram fruto de um processo histórico de décadas a séculos, aqui foram reconhecidos em um único ato, no que Boaventura de Sousa Santos chamou de "curto-circuito histórico". 8 Direitos reconhecidos sem o respaldo das políticas públicas pertinentes e da vontade política que os implementassem.

Resultado: o Judiciário virou a pretensa ponte tentando ligar esses dois espaços: o jurídico-programático e o pragmático-econômico. E na figura do magistrado, a aposta no novo redentor que resgataria as promessas perdidas de uma modernidade que só ocorreu nos Estados centrais. Seria a toga o manto mágico do "salvador da pátria", do guardião da moralidade. É o Messias. Mas fundamentado em quê? Eis o grande problema.

O Judiciário terminou alçado a uma condição de protagonista. E ao mesmo tempo em que triunfa, o Judiciário falha: não dá conta da demanda ${ }^{9}$ e nem está preparado para assumir a postura que dele se deve esperar em um Estado Democrático de Direito. A pretensa solução termina passando por posturas que

7 Constituição da República, art. 50: "§ 10 - As normas definidoras dos direitos e garantias fundamentais têm aplicação imediata".

8 SANTOS, Boaventura de Sousa. Para uma revolução democrática da justiça. 2. ed. rev. e ampl. São Paulo: Cortez, 2008, p. 20. Desde já se adianta que isso não quer dizer que tais direitos não devam ser exigidos ou que se defenda um processo paulatino de reconhecimento. O estamento vai sempre buscar ou a sonegação ou a protelação de conquistas sociais para manter seus privilégios, como foi a política da época de ditadura militar de "crescer o bolo para depois reparti-lo". A teoria da "reserva do possível", sempre que o "possível" implique redistribuição de renda ou futuro aumento de impostos a quem pode pagar, está aí para isso mesmo. Por falar em possibilidade, passados quase vinte cinco anos da Constituição Federal, por onde anda o projeto de lei complementar que institui o imposto sobre grandes fortunas (art. 153, VII, da Constituição Federal)?

9 SALDANHA, Jânia Maria Lopes. A jurisdição partida ao meio. A (in)visível tensão entre eficiência e efetividade. In Constituição, Sistemas Sociais e Hermenêutica. n. 6, p. 75100, Porto Alegre: Livraria do Advogado, 2010, p. 82-83. 
fogem da normatividade para buscar no utilitarismo uma solução. Mas a histórica cultura do autoritarismo na esfera pública e a falta de uma teoria da decisão e de uma teoria da interpretação jogam a decisão judicial no colo da vontade de poder de quem a profere. Mudam-se os atores e os personagens, mas os papéis continuam os mesmos nesse enredo. Assim, essa peça não caminha para um final feliz.

O controle do exercício do poder é um dos grandes desafios para o Estado Democrático de Direito que se almeja solidificar no Brasil. Esse desafio se torna ainda mais sério e grave quando o Poder encarregado de realizar a hermenêutica constitucional - e reafirmar os limites traçados por ela - ainda é aprendiz nessa matéria. Isso quando ele próprio não dá um mau exemplo. O desafio é apontar as linhas gerais de um novo caminhar que permita enxergar uma solução que não desague em mais arbitrariedade. No trajeto, trar-se-á o exemplo da experiência de ativismo judicial ocorrida na Alemanha, com o fim de demonstrar os seus riscos.

\section{A VONTADE E O PODER - UM EXEMPLO PARA ALÉM DO DIREITO}

Em um dos tópicos da obra Para Além do Direito, ${ }^{10}$ Richard Posner reflete sobre a justiça alemã durante o período do Reich. E tenta encontrar os motivos pelas quais os juízes alemães não resistiram à ideologia nazista, não questionaram as leis do regime ditatorial de Hitler. A comunidade jurídica alemã do pós-guerra apregoa que não o fizeram por temerem por suas vidas, somente, mas porque foram educados sob uma tradição positivista: o conteúdo do direito se esgotaria nos decretos das autoridades constituídas. Os juízes não poderiam modificá-los ou anulá-los com base no direito natural.

Mas esse ponto de vista é rechaçado fortemente, segundo Posner, em uma obra intitulada Hitler's Justice: The Courts of the Third Reich, ${ }^{11}$ de Ingo Müller. Segundo o autor, essa postura nada tem a ver com o positivismo legalista. Começa com Bismarck, que preencheu o Judiciário alemão com ultraconservadores cujo lema era "aquilo que faz o exército nas nossas fronteiras devem nossas decisões 10 POSNER, Richard. Para Além do Direito. Tradução Evandro Ferreira da Silva. São Paulo: Martins Fontes, 2009.

11 MÜLLER, Ingo. Hitler's Justice: The Courts of the Third Reich. Cambridge: Harvard University Press, 1991. 
fazer dentro delas". ${ }^{12}$ E mesmo sob a Constituição de Weimar, eles se mostraram uma força subversiva, adaptando e distorcendo as leis, de modo a interpretá-las com máximo rigor contra uns (os esquerdistas) e deixando impunes outros (os direitistas mais perigosos).

Para um ato de punição praticado por Hitler ao participar do Putsch de Munique, em 1923, embora a sentença mínima fosse de cinco anos e a máxima fosse ilimitada; Hitler estivesse em liberdade condicional - o que impedia a suspensão condicional da pena; e fosse estrangeiro ${ }^{13}$ (de nacionalidade austríaca - o que ensejaria deportação), foi sentenciado a uma pena de somente seis meses de prisão, a ser cumprida em um luxuoso castelo. A corte recusou a deportação sob a alegação de que "no caso de um homem como Hitler, de ideais e sentimentos tão alemães, a opinião desta corte é que os desígnios e propósitos da lei não se aplicam". ${ }^{14}$ Enquanto isso, os judeus eram punidos implacavelmente. Foram, inclusive, proibidos de advogar. E os juízes que não cederam ao totalitarismo perderam seus cargos. Leis flagrantemente inconstitucionais eram validadas sob as togas do Judiciário.

E livres dos judeus e dos democratas, o Judiciário mergulhou, de uma vez, nos ideais nazistas. As leis elaboradas sob a validade da Constituição de Weimar eram "nazificadas", uma vez que os juízes - identificados com a ideologia totalitária e desapegados da normatividade, pois a Constituição de Weimar lhe era um obstáculo - primeiro decidiram perseguir implacavelmente os judeus, os ciganos e os comunistas, protegendo os nacionais-socialistas e depois encontravam os fundamentos. Segundo relatado do Müller, no novo contexto, "os juízes deveriam emitir juízos de valor coerentes com a ordem jurídica nacional-socialista e com os desígnios das lideranças políticas; as pessoas poderiam ser punidas por um ato que, mesmo não estando previsto expressamente em nenhuma lei, merecesse". ${ }^{15}$

12 "What the army is a tour borders, our decisions must be within them!" (MÜLLER, Ingo. Hitler's Justice: The Courts of the Third Reich. Cambridge: Harvard University Press, 1991, p. 9).

13 "... 'every person found guilty of high treason is to receive a fine as well. The amount of the fine is not limited'. The same law stated: 'In the case of foreign nationals, the court must issue an order for deportation infringement of deportation order by imprisionment."' (MÜLLER, Ingo. Hitler's Justice: The Courts of the Third Reich. Cambridge: Harvard University Press, 1991, p 16).

14 MÜLLER, Ingo. Hitler's Justice: The Courts of the Third Reich. Cambridge: Harvard University Press, 1991, p 16.

15 POSNER, Richard A. Para além do direito. Tradução de Evandro Ferreira da Silva. São 
Depois vieram as leis raciais nazistas, mas todas com o beneplácito do Judiciário que decidia conforme a consciência dos seus julgadores.

Como foi possível isso acontecer em um país que é berço da filosofia moderna e contemporânea, de homens como Walter Benjamin, Carnap, Dilthey, Engels, Eschenmayer, Feuerbach, Fichte, Frege, Hartmann, Jaspers, Kant, Loewenstein, Rosa Luxemburgo, Maier, Marcuse, Marx, Nietzsche, Radbruch, Schopenhauer, Simmel, Stammler e Weber? Que dizer do Brasil, saído há menos de trinta anos de um regime de exceção?

\section{DA JUDICIALIZAÇÃO DA POLÍTICA AO ATIVISMO JUDICIAL}

A centralidade do Poder Judiciário hoje é inegável. Pode-se dizer que, na mudança paradigmática proporcionada pelo Estado democrático de Direito a partir de 1949, ocorreu um deslocamento do polo de tensão dos demais Poderes em direção à Justiça Constitucional. A judicatura entrou, definitivamente, no dia a dia da vida administrativo-política brasileira, interagindo, interferindo ou condicionando tanto a efetivação de direitos fundamentais das três gerações, quanto a definição de quais as políticas públicas para o atingimento desses fins pelo Estado. O problema é definir qual o limite dessa intervenção. É divisar o ativismo judicial da inevitável judicialização da política. Um Governo com um Judiciário ou um governo do Judiciário. Um Governo assentado na Constituição ou um Governo na toga e na vontade individual de quem a veste.

Para tanto, faz-se necessário o resgate da origem do ativismo no seu berço, o constitucionalismo norte-americano, como se deu sua importação e os efeitos aqui, diante da forma com que se fez a referida transposição das teorias. E nessa tarefa se ancora no trabalho mais atualizado hoje, de autoria da jurista gaúcha Clarissa Tassinari. ${ }^{16}$

Para Tassinari, a solução passa por uma teoria da decisão judicial que culmine na necessidade de respostas corretas no Direito (compreendidas como decisões

Paulo: Martins Fontes, 2009, p. 158.

16 TASSINARI, Clarissa. Jurisdição e ativismo judicial: limites da atuação do Judiciário. Porto Alegre: Livraria do Advogado, 2013. 
judiciais constitucionalmente adequadas), o que é feito com lastro na teoria desenvolvida por Lenio Streck, a partir da imbricação das ideias de Hans-Georg Gadamer e Ronald Dworkin.

Preliminarmente, porém, ela efetua necessária uma distinção entrejudicialização da política e ativismo judicial.

Para a compreensão da judicialização da política, é preciso estabelecer a existência de três elementos que se entrelaçam: Direito, Política e Judiciário. Segundo a autora, em relação aos dois primeiros, é inegável que há uma relação entre ambos. Não por menos, leciona Tassinari, "o constitucionalismo pode ser definido como uma tentativa jurídica (Direito) de oferecer limites para o poder político (Política), o que se dá por meio das Constituições." ${ }^{17}$

É inegável que a Constituição, em sua formação, teve um elemento político. Houve escolhas (conteúdo político) na decisão de instituí-la e no seu processo de elaboração (forma de Estado, forma de Governo, regime de Governo, sistema econômico, etc.). Isso refletirá futuramente nos sistemas jurídico, político, econômico e social balizados pela Constituição. O problema se lança quando a Política passa a ser utilizada judicialmente como um argumento corretivo do direito, ${ }^{18}$ tornando-se o que Lenio Streck chama de "predador externo da autonomia do direito".

A origem da judicialização da política no Ocidente é social e contingente. Ela não advém de uma vontade do julgador ou do Judiciário. É fruto de um reposicionamento do Judiciário feito pelo constitucionalismo pós-guerra e sua pretensão de transformação da sociedade. Para tanto, as Cartas Constitucionais trouxeram consigo um rol mais amplo de direitos (tanto em número quanto em grau - p.e., direitos difusos). Mais direitos geram mais demanda e, em razão de sua não implementação pelo Estado e/ou o não reconhecimento pelas instituições privadas, dá-se o aumento da litigiosidade, transferindo a resolução desses litígios ao palco judicial. ${ }^{19}$

17 TASSINARI, Clarissa. Jurisdição e ativismo judicial: limites da atuação do Judiciário. Porto Alegre: Livraria do Advogado, 2013, p. 28.

18 TASSINARI, Clarissa. Jurisdição e ativismo judicial: limites da atuação do Judiciário. Porto Alegre: Livraria do Advogado, 2013, p. 29.

19 STRECK, Lenio Luiz. Jurisdição constitucional e decisão jurídica. 3. ed. São Paulo: Editora Revista dos Tribunais, 2013, p. 744. 
Como salienta Tassinari, a judicialização é muito mais uma constatação do que vem ocorrendo na contemporaneidade do que uma postura a ser identificada (como positiva ou negativa) do Judiciário. ${ }^{20}$

Já em relação ao ativismo judicial, este ocorre quando o Judiciário, que deve se pautar pelo respeito à normatividade (isto é, decidir por meio de argumentos jurídicos), desvirtua sua atuação ao se fundar em argumentos morais ou de política. Se o fundamento da atuação do Judiciário é, exatamente, a existência de lesão ou ameaça de lesão a direito, é paradoxal quando em sua decisão ele lança argumentos extrajurídicos (morais ou de política) como razão de decidir. Como se pretender restabelecer a normatividade violando-a com argumentos que a desconhecem?

No mesmo sentido, Streck, para quem "um juiz ou tribunal pratica ativismo quando decide a partir de argumentos de política, de moral, enfim, quando o direito é substituído pelas convicções pessoais de cada magistrado (ou de um conjunto de magistrados)". ${ }^{21}$

O argumento jurídico reflete o respeito à normatividade - é uma garantia para o cidadão de que no julgamento pelo Judiciário uma regra geral (o texto normativo), válida para todos os que estão no seu feixe de incidência (princípio da isonomia), está sendo individualizada (na geração da norma do caso concreto). Já um argumento de política ou moral advém de uma escolha pessoal do julgador, não estando previamente definido e nem constituindo uma regra geral.

Eporterum conteúdo ideológico, comovisto no exemplo alemão, tem umalcance e gera consequências imprevisíveis... Depois não se pode queixar do ditado que diz (com palavras menos elegantes) que de nádegas de recém-nascidos e cabeça de juiz ninguém sabe o que vem. O juiz ativista age como se pudesse ser o arauto da (sua) moralidade e da (sua própria) correção política, desprezando, porém, o deficit democrático dessa postura. Da postura de autoridade à de autoritário é só um pequeno passo para o juiz, mas um grande abismo para a constitucionalidade.

20 TASSINARI, Clarissa. Jurisdição e ativismo judicial: limites da atuação do Judiciário. Porto Alegre: Livraria do Advogado, 2013, p. 32.

21 STRECK, Lenio Luiz. Verdade e Consenso: Constituição, hermenêutica e teorias discursivas. 4. ed. São Paulo: Saraiva, 2011, p. 589, nota de rodapé 123. 


\section{VONTADE DE PODER, POTESTAS E POTENTIA E PODER OBEDIENCIAL}

Diante desse quadro, é importante que se teçam algumas considerações acerca da questão da decisão judicial como ato de vontade - mas que vontade seria essa? Para tanto, trazem-se à baila as reflexões de Enrique Dussel. ${ }^{22}$

À época do chamado "descobrimento das Américas", como a Europa há séculos vivia em lutas internas, cruzadas e guerras contra povos estrangeiros, adquiriu know-how bélico. Nas Américas, os invasores europeus se depararam com povos militarmente menos desenvolvidos. ${ }^{23} \mathrm{E}$ assim, aqui foi possível exercer o domínio militar, primeiro, e depois político, econômico, cultural e religioso tanto sobre os povos conquistados que aqui já viviam quanto sobre os que foram trazidos como escravos. E com o passar do tempo, impondo-se e explorando as terras e os povos recém-conquistados, a Europa passou a assumir a posição de "senhor" e a julgar dominando o mundo. Após a revolução industrial, conseguiu, também, sobrepujar a Ásia e assumir a centralidade mundial.

Esse contexto - de não haver nenhum senhor sobre o ego eurocêntrico edificou uma concepção de poder exclusivamente como dominação. ${ }^{24} \mathrm{Em}$ face da inexistência de outro poder que lhe faça frente, o ego dominante passou a ser a definição do que pode fazer ao se deter o poder. Formou-se uma relação assimétrica com o mundo colonial: uma relação de domínio pelas metrópoles. A dominação do sujeito poderoso ante ao impotente era interpretada como a definição mesma de poder político, como algo natural (ideologia legitimante). ${ }^{25} \mathrm{As}$

22 DUSSEL, Enrique. Política de la Liberación. Volumen II: arquitetónica. Madri: Trotta, 2009.

23 DUSSEL, Enrique. Política de la Liberación. Volumen II: arquitetónica. Madri: Trotta, 2009, p. 22. Cabe acrescentar que havia culturas latinas mais desenvolvidas em vários aspectos do que a europeia. E a Ásia, à época, era o centro do mundo. Não há, entretanto, espaço suficiente para nos aprofundarmos no tema. Sugerimos a leitura do DUSSEL, Enrique. 1492: el encubrimiento del otro: hacia el orígen del "mito de la modernidade". La Paz: Biblioteca Indígena, 2008.

24 Max Weber retrata bem a visão ideológica capturada pelo paradigma eurocêntrico do poder exclusivamente como dominação e como vontade de poder - ao tratar do tema somente sob essa ótica (WEBER, Max. Economia e sociedade. Trad. Regis Barbosa; Karen Elsabe Barbosa. Vol. 1. Brasília: UNB, 2004).

25 Não por menos a expressão ainda hoje ouvida por aqui: "manda quem pode; obedece quem tem juízo". 
raízes da (de)formação social da América Latina - de altos níveis de desigualdade e de marcada diferenciação étnico-econômica -, e de nosso deficit democrático - constatado pelos tantos e periódicos episódios de estado exceção - advêm dessa nossa formação colonial.

Dussel busca, então, um fundamento positivo último que permita descrever a relação vontade-poder em um sentido forte, com pretensão de verdade e legitimidade, de onde se permitam criticar as descrições reducionistas de dito poder. ${ }^{26}$ E propõe uma reflexão ontológica - que não se preocupe com os entes, as coisas, os objetos (que são meramente ônticos), mas com os fundamentos ou com aquilo que sustenta o ser. A pergunta ontológica é: qual o fundamento de tudo o que se chama Político?

Ele faz uma distinção entre potentia - o ser oculto, o poder da própria comunidade) - e potestas (o fenômeno, o poder delegado por representação, exercido por ações políticas por meio das instituições).

A potentia (o poder originário, não dividido, indeterminado, referência última na construção de todas as categorias) da comunidade política (origem e lugar em que a potestas é gerada) é como o "ser", o fundamento da política (do político, do campo político como político). Tudo que se chama "político" terá que se fundar, em última instância, nessa potentia.

Dito em poucas palavras, a potentia é o poder da própria comunidade política; é (para) a pluralidade de todas as vontades por meio da mediação que reconheça o direito do outro, do distante do poder (que no exercício da vontade de poder é o oprimido) ser igual. Um poder que vem das bases, é positivo, da vida que quer viver e ter os meios de sobreviver. O poder político como potentia não é dominação ou opressão. É afirmação da comunidade. ${ }^{27}$

O poder visto como mera dominação autoritária é um reducionismo. ${ }^{28}$ Como 26 DUSSEL, Enrique. Política de la Liberación. Volumen II: arquitetónica. Madri: Trotta, 2009, p. 47.

27 DUSSEL, Enrique. Política de la Liberación. Volumen II: arquitetónica. Madri: Trotta, 2009, p. 60.

28 Para Dussel, há muitas falácias reducionistas atreladas ao político - pois se fixam em um aspecto importante, mas insuficiente. a) a política só como ação estratégica; b) a política só como teleologia instrumental meio-fim (um formalismo sem conteúdo); c) a política só 
explicado anteriormente, o poder político é clivado por uma diferença ontológica entre a potentia (o poder político existente difuso na comunidade política - fonte de todo poder estatal que é o povo) e a potestas (o mero exercício delegado do poder político institucionalizado). Nossa Constituição, aliás, traz a diferença ontológica entre potentia e potestas logo no seu art. $1^{\circ}$, parágrafo único, ao estabelecer que "Parágrafo único. Todo o poder emana do povo [potentia], que o exerce por meio de representantes eleitos [potestas] ou diretamente, nos termos desta Constituição."

A potestas se cliva, novamente, no exercício obediencial ${ }^{29}$ do poder delegado, exercício realizado pelas ações e no cumprimento das funções das instituições políticas que respondem às exigências da comunidade política, do povo. O poder obediencial é institucionalizado. E ele se desnatura quando há o exercício do poder que se afirma a si mesmo sem referência à potentia. A autorreferência, como última instância da potestas, é o exercício fetichizado ou corrompido do poder político.

Quando o ator político, que exerce o poder institucionalizado, afirma-se como a sede da autoridade ou como última instância do exercício do poder, é dizer, quando se desliza do exercício obediencial à autoafirmação do poder desde si, origina-se ontologicamente a fetichização, a corrupção e a desnaturação do poder em dominação, despotismo, tirania. A autonomização ou oposição da potestas (a aparência fenomênica) à potentia (seu fundamento ontológico) é a dissolução da política como tal. ${ }^{30}$

Infelizmente, dada a formação cultural, o manejo do poder e da coisa pública como própria termina sendo prática comum - até naturalizada. ${ }^{31}$ Quando a

como competição amigo-inimigo (Carl Schimitt); d) a política como hegemonia; e) a política só como consenso discursivo (Habermas); f) a política só como o espaço de negociação de acordos para resolução de conflitos; g) a política como superestrutura do econômico; h) a política como completamente independente do campo econômico; i) a política como a referência exclusiva ao Estado (como "tomada do poder") ou como a luta pela dissolução do Estado; j) a política só como a afirmação ou como a absoluta negação de princípios normativos (DUSSEL, Enrique. Política de la Liberación. Volumen II: arquitetónica. Madri: Trotta, 2009, p. 24-37).

29 Exercício obediencial no sentido de obedecer (ao povo, enquanto poder difuso e legitimante da autoridade) mandando.

30 DUSSEL, Enrique. Política de la Liberación. Volumen II: arquitetónica. Madri: Trotta, 2009 , p. 12.

31 Não por menos, em nosso dia a dia, é mais comum se ouvir o adágio, "manda quem pode, obedece quem tem juízo" - que representa uma concepção negativa do poder, do que o "o povo unido jamais será vencido", representando uma concepção positiva de poder. 
potestas se fetichiza, isto é, se distancia da potentia que a legitima e fundamenta, perde força, a ponto de, em havendo o desconhecimento da potentia, virar exercício despótico, mera vontade de poder.

\section{A VONTADE COMO FUNDAMENTO DA POTENTIA E DA POTESTAS -}

A VONTADE DE PODER

Segundo Dussel, antes de vontade de poder (como dominação - e que reproduz morte), há a vontade de fazer as mediações necessárias a se ouvir o outro, em se tratando do juiz, em se ouvir o poder como potentia, como povo. E o reconhecimento institucionalizado da potentia reside na Constituição, pois é ela quem expressamente determina, dentro de uma com unidade política, a obediência ao poder potentia - razão de todo o agir estatal. E essa legitimação, a quem Dussel dá o nome de "vontade de viver", opõe-se à vontade de poder que gera morte e opressão.

A vontade de viver não é voluntas que se atribui ao agente político delegado, mas à comunidade política e é fundamentalmente anterior a qualquer vontade de poder de um ator político (potestas), pois foi ela quem o legitimou como autoridade. ${ }^{32}$ Essa comunidade (potentia) é a verdadeira referência da vontade de viver. $\mathrm{O}$ agente político manda obedecendo essa vontade, e não o inverso.

O juiz é agente político. É membro de um poder delegado pelo poder potentia. Mas ele manda obedecendo também. A decisão judicial não é ato de vontade do juiz porque ele não tem esse poder de fazer valer sua vontade pessoal. Não fica a critério dele dizer o que quer sobre o que é direito, mas sim, fazê-lo dentro de sua esfera de atribuição de poder potestas, que se resume ao campo normativo.

\section{DECISÃO JUDICIAL: ATO DE VONTADE OU DE RESPEITO À} NORMATIVIDADE?

O caso da Alemanha é agudo, ilustrativo e sintomático. Revela os prejuízos à democracia que causam a permissibilidade de juízos de valor a partir da 32 DUSSEL, Enrique. Política de la Liberación. Volumen II: arquitetónica. Madri: Trotta, 2009, p. 59. 
consciência, entendida como subjetividade assujeitadora. ${ }^{33}$ As decisões judiciais terminam por se tornar uma roleta-russa, dada sua incerteza.

O direito não está à disposição do juiz. Ele não pode decidir conforme seus valores, pois os valores são um atributo pessoal, que advém da formação de cada um (ou da manipulação ideológica negativa a que possa estar sendo submetido, inclusive de modo a descolar suas decisões da normatividade). $O$ decidir pela consciência (enfim, do voluntarismo "pessoal"), além de perigoso, é retrógrado. Remete a um período pré-iluminismo. Volta-se ao Estado Absolutista, em que o monarca dizia o que era o direito. Juízes não são reis. Vive-se em uma República. Nela, o primado é da Lei e não da vontade (e da consciência lhe anima).

Mas por que decidir somente com base em argumentos jurídicos? ${ }^{34}$ Porque a sociedade tem uma garantia: o respeito à Constituição. Ninguém está acima dela. Ela é o norte do regime democrático porque condiciona todos a um regramento único.

\section{POR UMA TEORIA DA DECISÃO JUDICIAL}

Já se abordou a existência de um inegável conteúdo ideológico no discurso de poder. E que pretensas soluções são, muitas vezes utópicas, fora da realidade. Uma delas é apostar na discricionariedade judicial, que descamba para a vontade de poder de quem a profere. A solução está no desenvolvimento de uma teoria da decisão que parta da necessidade de se quebrar o paradigma da filosofia da consciência, tanto na sua vertente metodológica quando argumentativa. Para tanto, faz-se necessária a consideração da diferença ontológica entre texto e norma, do linguistic turn encabeçado por Wittgenstein, da filosofia hermenêutica de Heidegger e da hermenêutica filosófica de Gadamer e, por intermédio da teoria da resposta correta, de Ronald Dworkin. Com isso, edifica uma limitação

33 Nesse sentido, ver STRECK, Lenio Luiz. Jurisdição constitucional e decisão jurídica. 3. ed. São Paulo, Revista dos Tribunais, 2013, em especial os capítulos 5 e 6, em que é discutida a questão do esquema sujeito-objeto e suas consequências no âmbito do direito.

34 Direito é "um conceito interpretativo e é aquilo que é emanado pelas instituições jurídicas, sendo que as questões e ele relativas encontram, necessariamente, respostas nas leis, nos princípios constitucionais, nos regulamentos e nos precedentes que tenham DNA constitucional, e não na vontade individual do aplicador". STRECK. Lenio Luiz. Jurisdição constitucional e decisão jurídica. 3. ed. São Paulo, Revista dos Tribunais, 2013, p. 347. 
ao arbítrio judicial, de modo a possibilitar uma hermenêutica consentânea com o Estado Democrático de Direito - que não deve aceitar posturas ativistas.

A normatividade, como diz Dworkin, é expressão da isonomia. O juiz não recebeu um cheque em branco para fazer o que quiser, agir de acordo com seus valores pessoais no exercício da jurisdição. Juris dictio é dizer o direito. O direito que está na normatividade, no feixe de textos que têm por fundamento uma Constituição democraticamente promulgada. É a partir dela que as normas do caso concreto devem surgir, sempre.

Assim, não se aplaudem as práticas judiciais fundadas em decisões conforme a consciência. Ao contrário do que possa parecer, nelas está o ovo da serpente. O direito não está à mercê da composição dos tribunais. Não são eles que dizem o que é o direito ou o que é uma Constituição. Para Dworkin:

[...] ainda que os juízes devam sempre ter a última palavra, sua palavra não será a melhor por essa razão. A atitude do direito é construtiva: sua finalidade, no espírito interpretativo, é colocar o princípio acima da prática para mostrar o melhor caminho para um futuro melhor, mantendo a boa-fé com relação ao passado. É, por último, uma atitude fraterna, uma expressão de como somos unidos pela comunidade apesar de divididos por nossos projetos, interesses e convicções. Isto é, de qualquer forma, o que o direito representa para nós: para as pessoas que queremos ser e para a comunidade que pretendemos ter. ${ }^{35}$

Há constrangimentos epistemológicos que não podem ser ultrapassados. Vive-se dentro de uma tradição e as decisões precisam ser coerentes, respeitando a integridade do direito. Há conceitos que são compartilhados dentro de uma comunidade e não podem ser transmudados sem graves consequências democráticas. Não se repita o que se fez com a Constituição de Weimar.

Assim, por um lado, sempre que se enxerga algo, faz-se a partir de um determinado ponto. Nesse momento se faz boa a constatação de Zizek:

Ou, para usar o lacanês, o olhar do sujeito é sempre-já inscrito no objeto percebido em si, sob o disfarce de seu "ponto cego", que está 'no objeto mais que o objeto em si', ponto do qual o próprio objeto

35 DWORKIN, Ronald. O Império do direito. Tradução Jefferson Luiz Camargo. São Paulo: Martins Fontes, 2003, p. 492. 
devolve o olhar. "Com certeza a imagem está no meu olho, mas eu, eu também estou na imagem". ${ }^{36}$

Portanto, todos têm um lugar de fala e, a partir desse lugar, os preconceitos (aqui entendido como pré-juízos - juízos prévios) sobre um determinado fenômeno se formam. ${ }^{37}$ Mas, por outro lado, antes disso, se está inserido na linguagem e na cultura - em que as referências são intersubjetivamente compartilhadas por todos e que não se pode, como já dito - e nunca é demais repetir nesse ponto -, corrompê-las sem um prejuízo irreversível à coerência do discurso. Somente quando os preconceitos sobre algo se adequam à referência que a tradição atribui àquele fenômeno é que se pode falar em uma interpretação autêntica. ${ }^{38}$

Antes de se entender como subjetividade, precisa-se entender como identidades socialmente e culturalmente construídas. Está-se enraizado e incrustado num ambiente cultural específico. Esse ambiente específico é a tradição. A subjetividade deslocada (fora da história, da tradição e da facticidade e existência do intérprete) é uma falácia. ${ }^{39}$ Por isso a interpretação não é algo ao alvedrio da vontade do intérprete. E diz Gadamer:

O que o ser significa terá de ser determinado a partir do horizonte do tempo. A estrutura da temporalidade aparece assim como a determinação ontológica da subjetividade. Porém ela era mais do que isso. A tese de Heidegger era: o próprio ser é tempo. ${ }^{40}$

A linguagem é o que já está intersubjetivamente dado e não pode ser produto

36 ŽIŽEK, Slavoj. A visão em paralaxe. Tradução Maria Beatriz de Medina. São Paulo: Boitempo, 2008, p. 28.

37 Cabe aqui diferenciar pré-compreensão e preconceitos. A pré-compreensão é do nível do a priori, antecipador de sentido. A pré-compreensão é uma espécie de totalidade que não pode ser fatiada (como se existisse uma pré-compreensão religiosa e outra leiga/laica). Não nos perguntamos por que compreendemos, pela simples razão de que já compreendemos - lembrando aquilo que ensina Heidegger: em todo discurso, como um existencial do ser-aí, já há uma compreensibilidade sendo articulada. É por isso que Gadamer diz que o método chega tarde. A pré-compreensão não significa uma estrutura de caráter histórico e cultural que caracteriza uma posição que se prende a um conteúdo determinado, apresentado como válido contra outro conteúdo. O que está em questão aqui é o problema do preconceito, que pode aparecer na ideologia, na visão de mundo e nos conflitos de caráter histórico.

38 LAWN, Chris. Compreender Gadamer. Petrópolis: Vozes, 2007, p. 12.

39 LAWN, Chris. Compreender Gadamer. Petrópolis: Vozes, 2007, p. 94.

40 GADAMER, Hans-Georg. Verdade e método: traços fundamentais de uma hermenêutica filosófica. Tradução Flávio Paulo Meurer. 3. ed. Petrópolis: Vozes, 1999, p. 388. 
de um sujeito solipsista, que cria seu próprio objeto de conhecimento. Sem a mediação do significado, não há conhecimento das coisas e esse significado tem um horizonte predeterminado pela tradição. Dessa forma, nunca se tem acesso aos objetos como eles são, mas a partir de um ponto de vista que é fruto do modo de ser-no-mundo ${ }^{41}$, o que evidencia como reducionista qualquer visão que atribua a decisão judicial a um mero juízo de razão, fruto de um sujeito racional e capaz de ou assenhorar a coisa ou de extrair dela uma essência que ela mantém como própria, fruto de um ato de vontade.

O significado do que se interpreta não está na consciência do sujeito interpretante. Origina-se de um contexto de significantes e significados a que Heidegger chama de mundo. Mundo como instância em que o significado é encontrado e produzido em um contexto a priori e compartilhado. Está-se lançado em um mundo que é anterior e do qual não está ao dispor definir e determinar sua estrutura. Deslocar para uma suposta consciência isolada e autossuficiente à atribuição de sentido, apostando no individualismo do sujeito que constrói o seu próprio objeto de conhecimento, é criar uma falácia.

Importa-se muito mal a jurisprudência dos valores, pois não se refletiu sobre o contexto alemão que a forjou. ${ }^{42}$ Não se consideram as diferentes realidades históricas. Na Alemanha do pós-guerra, havia uma Constituição que não foi formada democraticamente com a participação do povo alemão, mas sim condicionada pelos aliados vencedores em 1949. Era preciso ir para além do texto legal, buscando os valores que se coadunassem com a realidade tedesca portanto, com aquela tradição.

A conjuntura brasileira é diversa. Sequer se conseguiu, na formação histórica, edificar um espaço democrático que permita fundar a legalidade sob a batuta constitucional. Nesse nível, o ativismo judicial surge como normal, aceitável ou até preferivel, afinal, há costumes autoritários no modo das autoridades agirem - agem como se não houvesse uma imensa diferença entre autoritas e

41 HEIDEGGER, Martin. Ser e tempo. Tradução de Márcia de Sá Cavalcante. 8. ed. Petrópolis: Vozes, 1999, p. 170.

42 STRECK, Lenio Luiz. Verdade e Consenso: Constituição, hermenêutica e teorias discursivas. 4. ed. São Paulo: Saraiva, 2011, p. 31. 
autoritarismo, e entre potentia e potestas, como já mostrado. No Brasil, aliás, há dificuldade entre se separar o que é público do que é privado. E não há espaço público democrático suficiente para discursos contrários.

Assim, o Judiciário surge como pai de uma sociedade infantilizada. Mas o mesmo pai protetor de hoje pode ser também tirânico do amanhã, pois sua concepção é solipsista, ficando a sociedade à mercê de posicionamentos pessoais dos magistrados e, em última palavra, da suprema corte. Hoje há aplausos e poucos reclamos. Mas o ovo da serpente está lá. O juris dictio não pode depender das convicções pessoais de onze homens. Nem de onze mil. A Alemanha apostou nisso e preparou o terreno para que os tanques de Hitler passassem, anos depois. O solipsismo chocou o ovo da serpente. Para quem não acredita na possibilidade de regressão a regimes totalitários, recomenda-se o filme "A ONDA", baseado em um experimento real. ${ }^{43}$

E se repete: o direito não é (e não pode ser) aquilo que o intérprete quer que ele seja. A decisão não deve ser fruto de um ato de vontade como queria Kelsen. Sentença judicial não pode advir de sentire. Pelo menos não em uma democracia. A interpretação não é fruto da subjetividade do juiz e muito menos produto da consciência do julgador. Não há valores a serem ponderados porque o direito é deontológico. Valores, cada um tem os seus. Mas os sentidos advindos da interpretação do direito posto são compartilhados dentro de uma comunidade. Um juiz não pode impor aos outros os seus próprios valores, não pode construir sua decisão com base em argumentos de política. Isso não é ser democrático. $O$ campo de atuação do juiz deve ser o normativo.

O sentido da interpretação não fica a dispor do intérprete. Há um problema filosófico-paradigmático que vem desde o século XIX sobre o papel destinado ao juiz. Vingou aqui uma visão solipsista de que o magistrado tem poderes além da lei. Não por menos a crítica de Werneck Vianna:

Ele é criatura de uma carreira burocrático-estatal, porém se concebe como um ser singular, auto-orientado, como se a sua investidura na função fizesse dele um personagem social dotado de carisma. Daí que, embora recrutado fora da política, isto é, pelo instituto do concurso

43 A ONDA (DAS WELLE). Diretor: Dennis Gansel, Produtor: Christian Becker. Local: Alemanha. 2008. DVD, 107 min. 
público, ele não se enquadre inteiramente no ethos burocrático preconizado por Max Weber. ${ }^{44}$

Para agravar o problema, a concepção instrumentalista do processo impera, trazendo consigo os escopos metajurídicos do processo, de cunho claramente utilitarista, não contidos no direito legislado. ${ }^{45}$ Sendo assim, mitiga-se, a priori, o alcance de princípios como o devido processo legal, em nome de valores como a eficiência e a economia (mesma isca utilitarista dos "valores" - o que, sob o argumento da defesa do espírito do povo alemão, o nazismo manipulou e usou tão eficientemente).

Observem que a expressão "decido conforme minha consciência" remete ou se interliga sempre a uma determinada ideia de "justiça". Mas o que é justiça afinal? É o que o juiz acha que é? Somente para ilustrar a fluidez e os riscos do juiz se apegar a um conceito de "justiça" conforme a sua consciência, e já que se inicia esse escrito abordando o totalitarismo nazista, Hitler também tinha o dele. E seu livro-manifesto "Mein Kampf"46, o mesmo homem que deu início a uma guerra que mataria cinquenta milhões de vidas, utilizou nada menos que trinta e sete vezes as palavras "justiça" ou "injustiça"; "justo", "justa", "injusto" ou "injusta", vinte vezes; e a palavra "justeza" dez vezes.

Mas não se interpreta para compreender e, sim, compreende-se para interpretar. ${ }^{47}$ A compreensão, no dizer de ensinar de Heidegger, é um existencial porque na medida em que se compreende algo, antes se compreende o ser, como demonstrado no $\$ 13$ de Ser e Tempo. ${ }^{48} \mathrm{E}$ a interpretação é a explicitação do compreendido e não o compreendido em si. Isso porque se vive em um mundo simbólico e na medida em que se expressa, via linguagem, os significantes são

44 VIANNA, Luiz Werneck et. al. Corpo e alma da magistratura brasileira. 3. ed. Rio de janeiro: Revan, 1997, p. 295.

45 "[...] se o texto aparenta apontar para uma solução que não satisfaça ao seu sentimento de justiça, isso significa que provavelmente as palavras do texto ou foram mal empregadas pelo legislador, ou o próprio texto, segundo a mens legislatoris, discrepa dos valores aceitos pela nação no tempo presente". DINAMARCO, Cândido Rangel. A instrumentalidade do processo. São Paulo: Malheiros, 2009, p. 248.

46 HITLER, Adolf. Minha luta. São Paulo: Centauro, 2001.

47 Nesse sentido, STRECK, Lenio Luiz. Verdade e Consenso: Constituição, hermenêutica e teorias discursivas. 4. ed. São Paulo: Saraiva, 2011, p. 23.

48 HEIDEGGER, Martin. Ser e tempo. Tradução Márcia de Sá Cavalcante. 8. ed. Petrópolis: Vozes, 1999, p. 39. 
interpretados pelo outros, gerando significados que não estão ao alvedrio da vontade, mas sim são frutos da práxis humana, intersubjetivamente construída. $E$, dessa forma, o intérprete sempre atribui sentidos. Mas o intérprete não pode retirar do texto algo que este não possui em si mesmo, pois tais sentidos não foram construídos por ele e, assim, não estão à sua disposição. Os textos não são pretextos para a decisão judicial. São o fundamento.

Desta forma, a concretização do direito não pode depender do esquema sujeito-objeto, de uma subjetividade assujeitadora, ${ }^{49}$ como se o sentido estivesse à disposição do intérprete porque tal pretensão não é factível. A interpretação não é ato de vontade, sob pena da discricionariedade transformar juízes em legisladores, com a pretensa razão humana passando a ser a fonte iluminadora do significado de tudo. Isso, sim, cega.

$\mathrm{O}$ atrelamento ao positivismo ${ }^{50}$ gera o uso e o abuso dos valores. Estes se tornam, nessa dimensão, enunciados performativos. E os princípios, sob uma ótica valorativa, como os antigos princípios gerais de direito, passaram a ser usados para a "criação judiciária", diga-se, discricionariedade, gerando o fenômeno que um dos coautores deste intitula de panprincipiologismo e em vários textos denuncia esse desvirtuamento dos princípios jurídicos, utilizados como pretexto para o exercício da pura vontade de poder. Aproveita-se para transcrever alguns até pitorescos:

[...] princípio da simetria (menos um princípio de validade geral e mais um mecanismo ad hoc de resolução de controvérsias que tratam da discussão de competências); princípio da precaução (nada mais, nada menos que a institucionalização de uma tautologia jurídica; afinal, por que a "precaução" - que poderíamos derivar da velha prudência seria um "princípio"?); (...) princípio da não surpresa (não passa de um enunciado com pretensões performativas, sem qualquer normatividade; de que forma uma demanda é resolvida utilizando o princípio da não surpresa?); (...) princípio da absoluta prioridade dos direitos da Criança e do Adolescente (interessante nesse standard retórico é a expressão "absoluta"...); princípio da afetividade (esse prêt-à-portêr nada mais faz do

49 STRECK, Lenio Luiz. O que é isto: decido conforme minha consciência? 2. ed. rev. e ampl. Porto Alegre: Livraria do Advogado, 2010, p. 93.

50 Refere-se, por óbvio, a um conceito de positivismo para além do velho exegetismo (positivismo primitivo). Essa discussão pode ser vista, mais amiúde, em STRECK, Lenio Luiz. Hermenêutica Jurídica $\mathbf{e}(\mathbf{m})$ crise: uma exploração hermenêutica da construção do direito. 10. ed. rev. e atual. Porto Alegre: Livraria do Advogado, 2011, p. 78-79. Portanto, também é positivista aquele que, em nome de sua subjetividade, constrói argumentos metajurídicos. 
que escancarar a compreensão do direito como subsidiário a juízos morais; daí a perplexidade: se os princípios constitucionais são deontológicos, como retirar da "afetividade" essa dimensão normativa?); princípio do processo tempestivo (mais uma amostra de uma "principiologia" ad hoc e sem limites, que confunde meros argumentos ou pontos de vista com princípios jurídicos); (...); principio do fato consumado (ora, se por vezes uma situação já consolidada deve ser mantida - fazendo soçobrar a "suficiência ôntica" de determina regra - isso não transforma a "consumação" de um fato em padrão que deva ser utilizado "em princípio"; fosse válido esse "princípio", estaríamos diante de um incentivo ao não cumprimento das leis, apostando na passagem do tempo ou na ineficiência da justiça); (...); princípio da instrumentalidade processual (trata-se de uma clara herança da filosofia da consciência e de uma leitura equivocada das teses de Von Büllow); (...) princípio da confiança no juiz da causa (serve para justificar qualquer decisão: para manter alguém preso e para soltar) (...)".51

Para se superar o positivismo, deve-se também superar o que o alicerça: o primado da subjetividade assujeitadora e o solipsismo da filosofia da consciência. ${ }^{52}$ E isso não se dá apostando em mecanismos vinculatórios, por exemplo, como se vem tentando. Essa pretensa solução ataca as consequências do problema. Não a causa. Eis aí uma clara utopia. ${ }^{53}$ Desta maneira, o caráter normativo dos princípios não pode servir como álibi exatamente para o que mais marcou o positivismo: a discricionariedade - como se pode ver nos exemplos já citados anteriormente em relação ao panprincipiologismo. A tese de abertura semântica dos princípios é incompatível com o pós-positivismo. A resposta constitucionalmente correta não pode depender do livre convencimento, da busca da suposta "verdade real" ou da consciência do juiz. Decidir não é, definitivamente, escolher.

A decisão se dá, não a partir de uma escolha, mas a partir do comprometimento com algo que se antecipa. ${ }^{54}$ No caso da decisão jurídica, esse algo que se antecipa

51 STRECK, Lenio Luiz. Hermenêutica Jurídica $\mathbf{e}(\mathbf{m})$ crise: uma exploração hermenêutica da construção do direito. 10. ed. rev. e atual. Porto Alegre: Livraria do Advogado, 2011, p. 147-149.

52 STRECK, Lenio Luiz. Verdade e Consenso: Constituição, hermenêutica e teorias discursivas. 4. ed. São Paulo: Saraiva, 2011, p. 498.

53 A maior debilidade da utopia: no instante em que se apresenta, abre as portas para caminhos que podem ser piores do que os atualmente trilhados. Isso porque a utopia é ausente de uma reflexão de caráter prático e político sobre suas consequências na realidade existente e nas instituições - e do que Ricoeur denomina de "o verossímil de uma época determinada" (RICOEUR, Paul. Educacion y politica: de la historia personal a la comunión de liberdades. Buenos Aires: Editoral docencia, 1984, p. 97).

54 STRECK, Lenio Luiz. O que é isto: decido conforme minha consciência? 2. ed. rev. e ampl. Porto Alegre: Livraria do Advogado, 2010, p. 106. 
é a compreensão daquilo que a comunidade política constrói como direito. Por isso as decisões não devem ser tomadas a partir de critérios pessoais. É assim que se faz a superação do paradigma da filosofia da consciência. Com assevera Rosivaldo Toscano,

O Judiciário nazista foi extremamente eficiente, não há dúvida. A vontade de poder como fundamento do agir estatal foi seu fundamento. E todos sabemos o resultado catastrófico. Antes de se defender um critério qualquer de utilidade que paute a decisão judicial, deve-se recordar os maus exemplos. Decidir conforme a consciência ou a vontade? Há um risco aí. ${ }^{55}$

É bem verdade que o histórico de desmandos e de autoritarismo, de concentração e mau uso do poder pelo estamento é causa da perda de credibilidade nas instituições e da eclosão de discursos de autoridade (e também autoritários) de "salvadores da pátria", o que colide diretamente com a ideia de poder obediencial desenvolvida por Dussel - abrindo brechas para que a vontade de poder seja exercida como pura dominação. E a bola da vez são os membros do Judiciário, inegavelmente. Mas em um Estado Democrático de Direito não se admite, sob a ótica dos direitos fundamentais e, em especial, sob o princípio da isonomia, entender que um membro de Poder possa decidir de acordo com sua consciência, com suas convicções pessoais, com base em seus valores.

O juiz é um ator político, no sentido em que representa o Poder Constituído. Mas ele não age ao alvedrio das próprias regras que o legitimaram como tal agente de poder. Assim como não há liberdade absoluta, o juiz é livre, por assim dizer, para decidir, mas sempre dentro de uma esfera de normatividade que constitui seu mundo decisório. Se há o dever constitucional de fundamentar suas decisões, há, acima disso, a necessidade de respeitar as regras do jogo democrático. $O$ juiz não cria o direito - não no sentido de inovar o ordenamento jurídico com a geração de normas que não tenham um texto normativo que lhes sirva de esteio. A diferença ontológica entre texto e norma precisa ser considerada e respeitada. Não há texto sem norma e, igualmente, também não há norma sem texto.

55 SANTOS, JÚNIOR, Rosivaldo Toscano dos. Controle remoto e decisão judicial: quando se decide sem decidir. Rio de Janeiro: Lumen Juris, 2014, p. 168. 
A vontade de poder põe em seu vazio ético razões de utilidade - que podem ser expressas ou ocultas por meio da interpretação inautêntica. Cabe aqui, portanto, uma advertência: o juiz que interpreta inautenticamente (Heidegger) - fora da tradição (Gadamer) e sem respeitar a integridade e a coerência em suas decisões (Dworkin) - não difere muito do déspota. A distância, na práxis forense, entre ser autoridade e ser autoritário é pequena. Mas o abismo que os separa é profundo.

De bom alvitre, nessa altura, os alertas dos coautores deste escrito.

'Paradoxalmente, depois dessa revolução copernicana representada pelo acentuado grau de autonomia do direito conquistado no Estado Democrático de Direito, está-se diante de uma crescente perda dessa característica, o que pode ser interpretado simbolicamente nesses tempos difíceis de pós-positivismo, a partir das diversas teses que apostam na análise econômica do direito, no interior das quais as regras e os princípios jurídico-constitucionais só têm sentido funcionalmente. Ou seja, em uma dimensão absolutamente pragmática, o direito não possui 'DNA'. 56

[...] construímos, historicamente, uma ideia de poder como dominação, da potentia desprovida de potestas, esquecendo a diferença ontológica que, todavia, nunca as separa. Isso explica o estamento e o patrimonialismo, bem como as posturas solipsistas - puro exercício da vontade de poder - horizontalmente consideradas (atribuição inautêntica de sentidos; utilização de princípios ad-hoc e de conceitos assertóricos). ${ }^{57}$

\section{CONSIDERAÇÕES FINAIS}

É uma utopia e um erro grosseiro acreditar que o chamado discurso de limitação do ativismo judicial é um luxo ao qual se pode renunciar ou que seria uma tese conservadora. E os resultados de uma utopia podem ser muito piores do que a realidade já estabelecida. Deve-se, pelo contrário, prevenir--se de discursos que, sob o pretexto de vanguardistas, violam direitos constitucionais.

56 STRECK, Lenio Luiz. Verdade e Consenso: Constituição, hermenêutica e teorias discursivas. 4. ed. São Paulo: Saraiva, 2011, p. 44.

57 SANTOS, JÚNIOR, Rosivaldo Toscano dos. Controle remoto e decisão judicial: quando se decide sem decidir. Rio de Janeiro: Lumen Juris, 2014, 
A mão que é capaz de proteger é a mesma que capaz de perseguir... O respeito à normatividade é sempre uma garantia contra desmandos, contra o exercício do arbítrio e da vontade de poder.

Histórias como as relatadas no livro de Ingo Müller fazem refletir sobre a importância de se pôr no lugar do outro. Isto é, ter alteridade. A alteridade que possibilita o crescimento, para que não se fossilize em pretensas verdades. E os efeitos e os perigos são muito maiores quando há relações de poder estatal em jogo, como a história alemã mostrou.

Trata-se de uma luta constante das próprias muralhas, para se impedir que assuma o poder esse pequeno Hitler que existe, potencialmente, em cada um de nós. Sempre haverá o poder. E o desejo de poder no ser humano (somos Nietzscheanos, nesse ponto) que tende à destruição e opressão. Não se crê, também, que o poder seja algo apropriável. O poder é exercício. E sua legitimação se dá numa relação tanto de cima para baixo quando de baixo para cima e da periferia para o centro e vice-e-versa, como foi o que ocorreu na Alemanha. Hitler só cresceu porque tinha efetivo apoio popular. Disso a sociedade alemã não pode se escusar.

Assim, como o poder não é algo apropriável, não haverá revoluções e nem regime únicos mundiais que "tomem" o poder (nem socialistas e muito menos capitalistas). Crê-se, todavia, que a ética também habita o humano. É um dever ético de cada cidadão resistir e denunciar a opressão do poder exercido de maneira desmedida.

O poder desmedido, portanto, oprime, pois é sempre a sujeição indigna do outro a uma vontade de poder. E a ideologia funciona negativamente, muitas vezes, de forma a que até mesmo o opressor imediato aja no interesse do poder de outrem, imaginando seu.

Enfim, a experiência da Alemanha, berço da filosofia moderna e contemporânea, demonstra que nunca se pode dizer que se alcançou a democracia plena. O que o nazismo, então, tem a ensinar? Que a democracia é um processo - sempre inconcluso e que em vez de se aborrecer, deve-se sempre agradecer pela oportunidade de se deparar com ideias opostas à que são propaladas pelo discurso hegemônico. A democracia é, antes de tudo, uma jornada, uma grande 
caminhada. Pede uma atenção e um cuidado constante a cada passo dado, a cada desvio possível e sedutor, a cada ponte ou abismo.

\section{REFERÊNCIAS}

A ONDA (DAS WELLE). Diretor: Dennis Gansel, Produtor: Christian Becker. Local: Alemanha. 2008. DVD, $107 \mathrm{~min}$.

DINAMARCO, Cândido Rangel. A instrumentalidade do processo. São Paulo: Malheiros, 2009.

DUSSEL, Enrique. 1492: el encubrimiento del otro: hacia el orígen del "mito de la modernidade". La Paz: Biblioteca Indígena, 2008.

DUSSEL, Enrique. Política de la Liberación. Volumen II: arquiteónica. Madri: Trotta, 2009.

DWORKIN, Ronald. O Império do direito. Tradução Jefferson Luiz Camargo. São Paulo: Martins Fontes, 2003.

FAORO, Raymundo. Os donos do poder: formação do patronato político brasileiro. 4. ed. São Paulo: Globo, 2008.

GADAMER, Hans-Georg. Verdade e método: traços fundamentais de uma hermenêutica filosófica. Tradução Flávio Paulo Meurer. 3. ed. Petrópolis: Vozes, 1999.

HEIDEGGER, Martin. Ser e tempo. Tradução de Márcia de Sá Cavalcante. 8. ed. Petrópolis: Vozes, 1999.

HITLER, Adolf. Minha luta. São Paulo: Centauro, 2001.

LAWN, Chris. Compreender Gadamer. Petrópolis: Vozes, 2007.

MÜLLER, Ingo. Hitler's Justice: The Courts of the Third Reich. Cambridge: Harvard University Press, 1991.

POSNER, Richard A. Para além do direito. Tradução de Evandro Ferreira da Silva. São Paulo: Martins Fontes, 2009.

REIS, Thiago. Quase metade da nova Câmara dos Deputados será formada por milionários. G1 Eleições, do Portal Globo.com. Disponível em: http://g1.globo.com/politica/eleicoes/2014/ blog/eleicao-em-numeros/post/quase-metade-da-nova-camara-dos-deputados-seraformada-por-milionarios.html. Acesso em: 23 jul. 2015. 
RICOEUR, Paul. Educacion y politica: de la historia personal a la comunión de liberdades. Buenos Aires: Editoral docencia, 1984.

SALDANHA, Jânia Maria Lopes. A jurisdição partida ao meio. A (in)visível tensão entre eficiência e efetividade. In Constituição, Sistemas Sociais e Hermenêutica. n. 6, p. 75-100, Porto Alegre: Livraria do Advogado, 2010.

SANTOS, Boaventura de Sousa. Para uma revolução democrática da justiça. 2. ed. rev. e ampl. São Paulo: Cortez, 2008.

SCHILLING, Voltaire. Estados Unidos e América Latina: da doutrina Monroe à Alca. 5. ed. Porto Alegre: Leitura XXI, 2002.

SANTOS, JÚNIOR, Rosivaldo Toscano dos. Controle remoto e decisão judicial: quando se decide sem decidir. Rio de Janeiro: Lumen Juris, 2014.

STRECK, Lenio Luiz. Hermenêutica Jurídica e(m) crise: uma exploração hermenêutica da construção do direito. 10. ed. rev. e atual. Porto Alegre: Livraria do Advogado, 2011.

STRECK, Lenio Luiz. Jurisdição constitucional e decisão jurídica. 3. ed. São Paulo, Revista dos Tribunais, 2013.

STRECK, Lenio Luiz. O que é isto: decido conforme minha consciência? 2. ed. rev. e ampl. Porto Alegre: Livraria do Advogado, 2010.

STRECK, Lenio Luiz. Verdade e Consenso: Constituição, hermenêutica e teorias discursivas. 4. ed. São Paulo: Saraiva, 2011.

TASSINARI, Clarissa. Jurisdição e ativismo judicial: limites da atuação do Judiciário. Porto Alegre: Livraria do Advogado, 2013.

VIANNA, Luiz Werneck et. al. Corpo e alma da magistratura brasileira. 3. ed. Rio de janeiro: Revan, 1997.

WEBER, Max. Economia e sociedade. Trad. Regis Barbosa; Karen Elsabe Barbosa. Vol. 1. Brasília: UNB, 2004.

ŽIŽEK, Slavoj. A visão em paralaxe. Tradução Maria Beatriz de Medina. São Paulo: Boitempo, 2008.

Recebido em: ago/2015

Aprovado em: mai/2016 